\title{
INFLUENCE OF NANOMODIFIERS ON THE PROPERTIES OF CONCRETE
}

\section{Shishkina A. A., Shishkin A. A.}

\section{INTRODUCTION}

It is expedient to use fine-grained concretes for production of thinwalled, densely reinforced and other designs at which manufacturing there is a restriction in the size of a filler. Such concretes are a multicomponent composite system ${ }^{1}$ and contain both fine-grained aggregate and fine aggregate, as well as Portland cement ${ }^{2}$ and highly effective superplasticizers, which act as deflocculants.

Optimal use allows you to control the rheological properties of concrete mixtures. In this case, it is also possible to change the structure of cement stone at the macro level. This allows to provide specific properties that provide high operational reliability of structures made using nanotechnology ${ }^{3}$, in particular with the use of artificial raw materials ${ }^{4}$.

One of the ways to modify the structure of fine-grained concrete is the use of micellar catalysis in the preparation of both dense powder concrete $^{5}$ and other types of concrete ${ }^{6}$.

${ }^{1}$ Murthy A.R.C., Palani G.S., Iyer N.R. Impact Analysis of Concrete Structural Components. Defense Science Journal. 2010. No. 60(3). Pp. 307-319.

Каприелов С.С., Шейнфельд А.В., Кардумян Г.С. Новые модифицированные бетоны : монографія. Москва : Парадиз, 2010. 258 с.

3. Haifeng L., Jianguo N. Mechanical behavior of reinforced concrete subjected to impact loading. Mechanics of Materials. 2009. Issue 41(12). Pp. 1298-1308.

4. Iqbal M.A., Rajput A., Bhargava P. Plain and reinforced concrete targets subjected to projectile impact. Procedia Engineering. 2017. Issue 173. Pp. 138-144.

3 Пономарев А.Н. Высококачественные бетоны. Анализ возможностей и практика использования методов нанотехнологии. Инженерно-строительный журнал. 2009. Вып 6. С. 25-33.

${ }^{4}$ Толстой А.Д., Лесовик В.С., Загороднюк ЈІ.Х., Ковалева И.А. Порошковые бетоны с применением техногенного сырья. Вестник МГСУ. 2015. Вып. 11. С. 101-109.

${ }^{5}$ Шишкіна О.О. Дослідження впливу нанокаталізу на формування міцності реакційного порошкового бетону. Восточно-Европейский журнал передовых технологий. 2016. Вып. 1/6 (79). С. 55-60. 
Due to the multifunctional action of deflocculants, plasticizers and micelles of surfactants, research aimed at further improvement and development of fine-grained concrete technology should be considered relevant. These studies should be aimed at regulating the processes of structure formation of cement stone by using effective additives that modify the structure of concrete.

\section{Analysis of literature data and problem statement}

The urgent need to obtain high-strength concrete on the basis of ordinary cements forces to look for new technological methods, the use of mineral additives-modifiers and organic modifier. It was proposed to use wastes of metallurgical productions as modifier additives ${ }^{7}$. Works ${ }^{8}$ and others established that the use of active mineral additives gives a real opportunity to obtain concretes with specified physical and mechanical characteristics with significant savings of Portland cement. However, the results of studies on the simultaneous use of micelles of surfactants with mineral additives-modifiers are not given.

Microsilica ${ }^{9}$ and metakaolin ${ }^{10}$ are currently the most widely used as modifier additives. However, they have certain disadvantages that constrain the widespread use of these additives. Such disadvantages of microsilica include the lack of stability of its properties, as it is a waste product. For metakaolin the disadvantage is its high cost due to the

6 Шишкіна О.О. Дослідження впливу поверхнево-активних речовин, що утворюють міцели, на міцність ніздрюватого реакційного порошкового бетону. Восточно-Европейский журнал передовых технологий. 2016. Вып. 2/6 (80). С. 66-70.

9. Shishkina A., Shishkin A., Vatin N. Low-shrinkage alcohol cement concrete. Applied Mechanics and Materials. 2014. Vols. 633-634. Pp. 917-921.

7 Батраков, В.Г., Каприелов С.С., Иванов Ф.М., Шейнфельд А.В. Оценка ультрадисперсных отходов металлургических производств как добавок в бетон. Бетон и железобетон. 1990. Вып. 12. С. 15-17; Баженов, Ю.М. Технология бетона. Москва : АВС, 2003. 500 с.

${ }^{8}$ Рунова, Р.Ф., Руденко И.И., Троян В.В., Товстонис В.В., Щербина С.П., Пашина Л.Д. Формирование структуры высокопрочных бетонов. Будівельні матеріали, вироби та санітарна техніка. 2008. Вип. 29. С. 91-97.

9 Барабаш И.В., Ксьоншкевич Л.М., Крантовська О.М. Високоміцні бетони на механоактивованому в'яжучому. Збірник наукових праць УкрДАЗТ. 2014. Вип. 149. С. 130-136.

14. Jo B.-W. Characteristics of cement mortar with nano-SiO $\mathrm{S}_{2}$ particles. Construction and Building Materials. 2007. No 21. Pp. 1351-1355.

10 Морозов Н.М., Боровских И.В. Влияние метакаолина на свойства цементных систем. Известия КГАСУ. 2015. Вып. 3(33). С. 127-132. 
relatively high energy consumption for its production. In addition, known additives-modifiers have been used simultaneously with superplasticizers and hyperplasticizers, which act as deflocculants.

However, such studies were carried out without taking into account the results of studies in the field of micellar catalysis of reactions of synthesis of calcium hydrosilicates, which showed the possibility of using d-element compounds as modifier additives ${ }^{11}$.

Therefore, there is reason to believe that there is insufficient certainty of the effect of known additives-modifiers simultaneously with micelles of surfactants on the characteristics of nanostructures formed during hydration of Portland cements. In particular, the main characteristic of the formation of the concrete structure is the compressive strength, which necessitates research in this direction.

The aim of this work is to determine the effect of modifier additives, namely kaolin, gypsum, lime and microsilica, as well as polymers modified by micelles of colloidal surfactant, on the strength of finegrained concrete and the rate of its formation.

To achieve this goal the following tasks were solved:

- to determine the optimal values of the consumption of additivesmodifiers modified by micelles of colloidal surfactant, to obtain finegrained concrete of maximum strength;

- to compare the effectiveness of the effect of additives-modifiers modified by micelles of colloidal surfactant on the strength of finegrained concrete.

The research was carried out using Portland cement CEM I 42.5 in accordance with EN 197-1 (manufacturer PJSC "Heidelberg cement Kryvyi Rih", Ukraine), as a fine aggregate used Dnieper river sand, the particle size characteristics of which are given in table. 1. Sodium oleate (Simagchem Surp., China) was used as the micelle-forming surfactant (MPA). Microsilica (trademark Elkem Microsilica Grade 940-U, SiO2 content 94.6\%), gypsum construction G-4 (PJSC Gipsovyk, KamyanetsPodilsky, Ukraine), slaked lime and kaolin of the Polonivskoye deposit were used as modifier additives (Khmelnytsky region, Ukraine), styrene acrylate.

The size of the specific surface of Portland cement, gypsum, lime and microsilica is given in table 2 .

11 Шишкін О.О. Дослідження впливу сполук перехідних елементів на міцелярний каталіз формування міцності реакційного порошкового бетону. Восточно-Европейский журнал передовых технологий. 2016. Вып. 2/6 (80). C. 60-65. 
Table 1

Particle size distribution of the aggregate

\begin{tabular}{|c|c|c|c|c|c|c|c|}
\hline \multirow{2}{*}{ filler } & True & Bulk & \multicolumn{5}{|c|}{ Partial residues on sieves, \% } \\
\cline { 5 - 9 } & $\begin{array}{c}\text { density, } \\
\mathbf{k g} / \mathbf{m}^{3}\end{array}$ & $\begin{array}{c}\text { density, } \\
\mathbf{k g} / \mathbf{m}^{\mathbf{3}}\end{array}$ & $\mathbf{2 . 5}$ & $\mathbf{1 . 2 5}$ & $\mathbf{0 . 6 3}$ & $\mathbf{0 . 3 1 5}$ & $\mathbf{0 . 1 6}$ \\
\hline $\begin{array}{c}\text { Dnieper river } \\
\text { sand }\end{array}$ & 2600 & 1490 & - & 12.1 & 26.9 & 32.6 & 28.4 \\
\hline
\end{tabular}

Table 2

Characteristics of additives-modifiers

\begin{tabular}{|c|c|}
\hline Substance & Specific surface, $\mathbf{~}^{\mathbf{2}} \mathbf{/ k g}$ \\
\hline Cement & 325 \\
\hline Microsilica & 14000 \\
\hline Lime & 298 \\
\hline Gypsum & 352 \\
\hline Styrene acrylate & - \\
\hline
\end{tabular}

Modification of additives-modifiers was carried out by treatment with an aqueous micellar solution of MPAR, which had a concentration of MPAR $0.1 \%$.

Experimental concrete samples were prepared from concrete mixtures, the components of which were dosed in the required quantities according to the experimental plan, mixed in a laboratory mixer for 3 minutes. The resulting mixture was placed in a metal mold-cube having a side size of $7 \mathrm{~cm}$ Thus formed concrete samples hardened for 28 days at an ambient humidity of $70 \pm 10 \%$ and an ambient temperature of $293 \pm 2 \mathrm{~K}$. Compressive strength of concrete that did not contain the micelle of the colloidal surfactant and additives-modifiers was 16.2 MPa.

The following independent factors varied in the experiment:

$\mathrm{X} 1$ - content of mineral additive-modifier in concrete;

X2 - MPAR content in concrete;

$\mathrm{X} 3$ is a type of mineral additive-modifier in concrete.

Indirect evaluation of the effect of modifiers on the strength of concrete was carried out based on the results of determining the compressive strength of fine-grained concrete. The composition of concrete was assumed to be constant in all studies with a ratio of "cement/fine aggregate" $=1 / 2$, with a constant water-solid ratio of 0.5 . Determination of the compressive strength of the samples was performed 
in accordance with standard methods. The strength of the samples was monitored on a universal machine UMM-100.

Conditions of homogeneity of the experiment were checked by parallel determinations of concrete strength of each composition.

\section{The results of research on the properties of concrete samples}

The results of determining the mechanical strength in compression of samples of fine-grained concrete at a certain stage of hardening (28 days) are presented in Fig. 1-5.

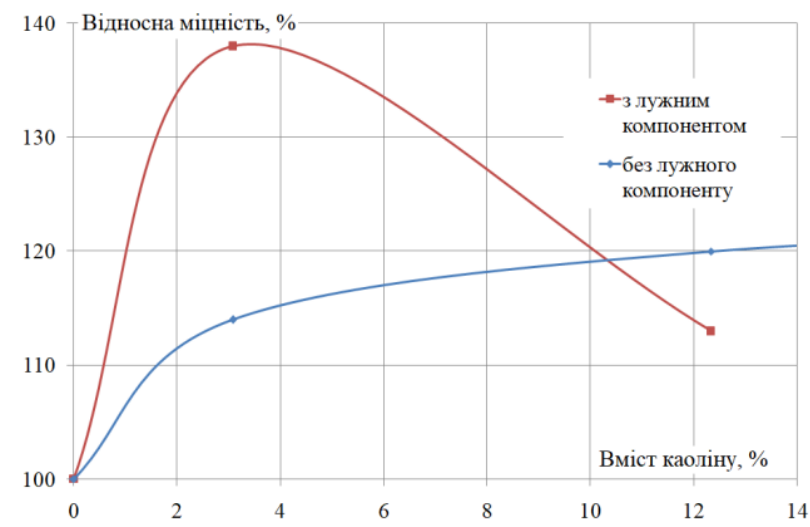

Fig. 1. The effect of modified kaolin on the strength of fine-grained concrete (MPAR content $-\mathbf{0 . 0 0 0 4 \%}$ )

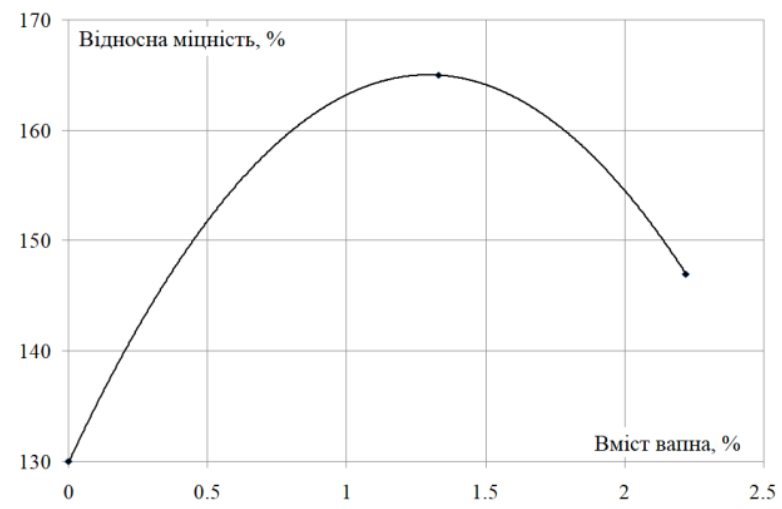

Fig. 2. The effect of modified lime on the strength of fine-grained concrete (MPAR content $-\mathbf{0 . 0 0 0 4 \%}$ ) 


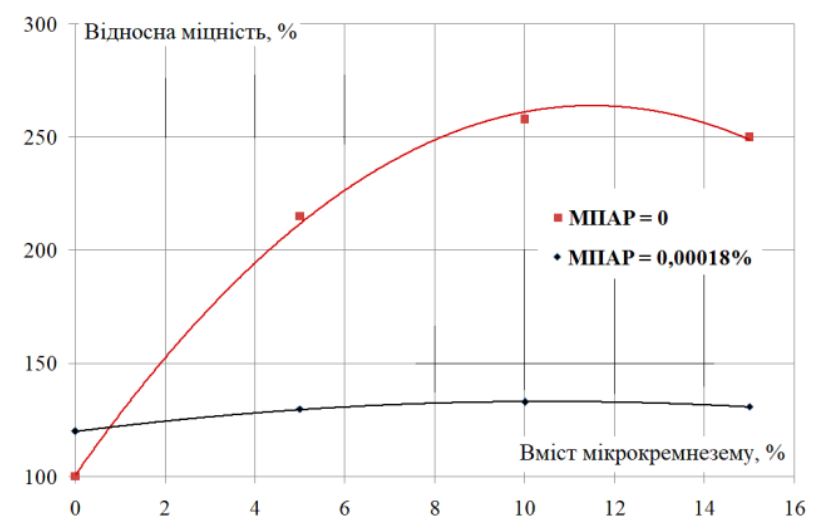

Fig. 3. Influence of modified microsilica on the strength of fine-grained concrete

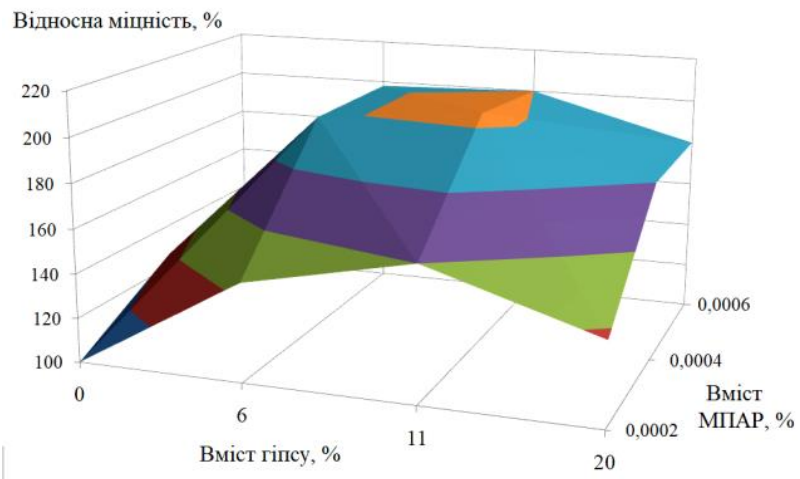

Fig. 4. Influence of modified gypsum on the strength of fine-grained concrete

It should be noted that in the presence of micelles of colloidal surfactant used additives-modifiers provide increased strength of finegrained concrete. For each additive-modifier there is a certain amount in the concrete, which ensures that it achieves maximum strength.

On the example of application as additives-modifiers of gypsum and styrene-acrylate it is established that there is a certain content of MPAR and additives-modifier (Fig. 4, 5) which provide achievement by concrete of the maximum durability at compression. 
According to experimental data to determine the rate of strength formation under compression of fine-grained concrete (Fig. 6, 7) it is seen that the increase in the rate of strength formation occurs due to the presence in the system of micelles of colloidal surfactants.

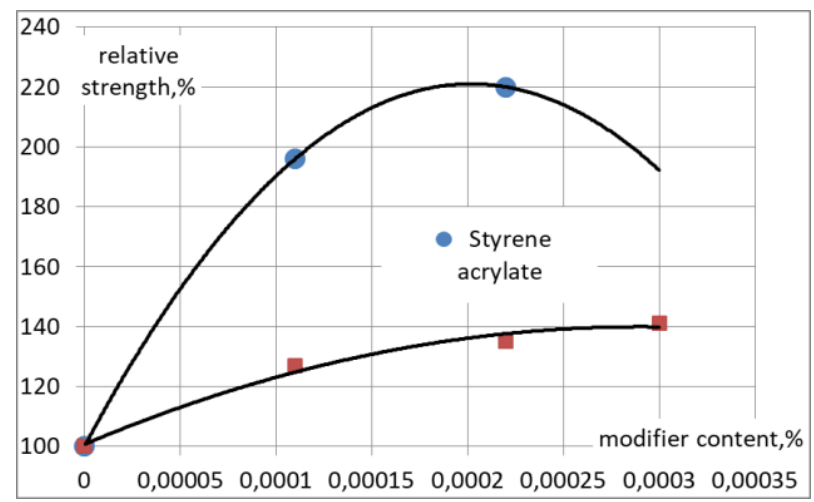

Fig. 5. The effect of styrene-acrylate emulsion on the strength of fine-grained concrete

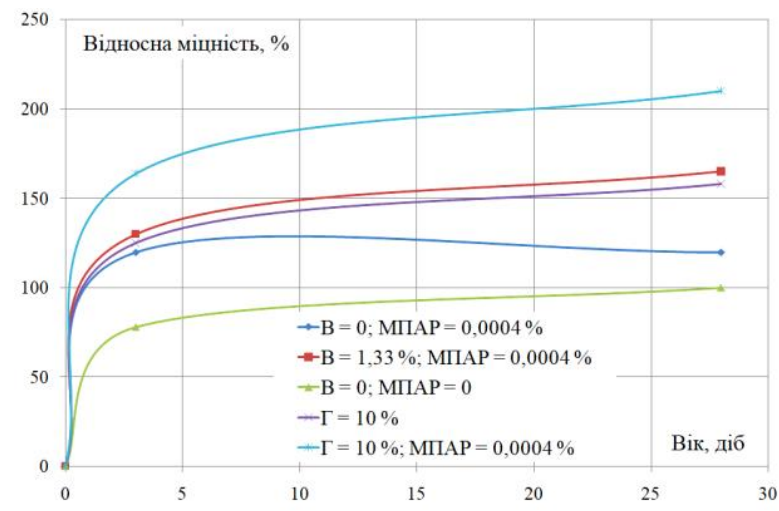

Fig. 6. Change in the strength of fine-grained concrete containing as an additive modifier lime (B) and gypsum (D), over time 


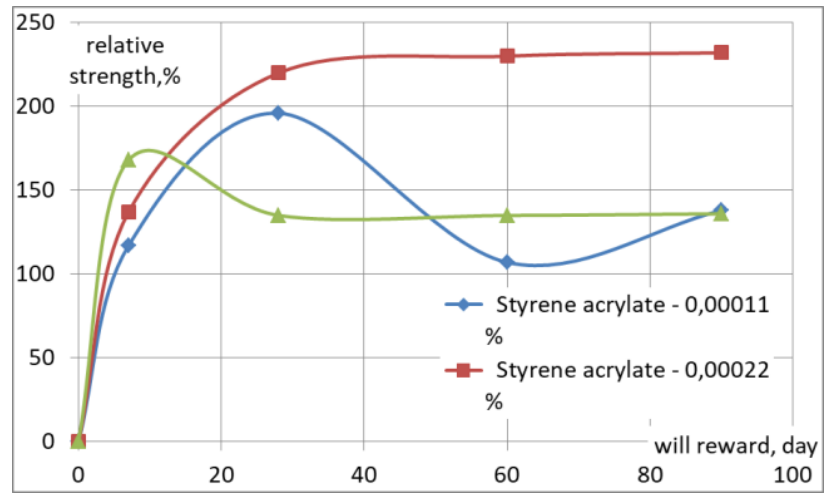

Fig. 7. The effect of styrene-acrylate emulsion on the strength of fine-grained concrete

The research results show that the type of mineral additive-modifier affects the strength of fine-grained concrete and can be used to analyze the effect of nanomodifiers depending on their type.

Thus, the use of a solution of sodium oleate to obtain concrete leads to an increase in the amount of bound water in the concrete, which indicates the acceleration and deepening of the hydration of minerals in the cement. The revealed effect can be explained only by considering the change in the ionic product of water, which is caused by sorption on the surface of the hydrocarbon part of sodium oleate of hydroxyl groups of water. In the optimal concentration range (in this case $10^{-4} \ldots 10^{-6} \mathrm{M}$ ) a fractal volume grid is formed, which occupies a significant volume in the aqueous system, and a local change in the concentration of hydroxyl groups near the molecules of sodium oleate leads to capacitive effect of change $\mathrm{pH}$.

This acidification of the suspension is favourable for creating conditions for the formation of the structure of cement stone, because in this case a neutralization reaction between the most soluble form of calcium hydroxide cement and the formation of additional water molecules, which subsequently bind to less soluble hydration products of Portland cement. At the same time, it is doubtful that under certain conditions nanoparticles - molecules of sodium oleate due to the effect of hydrophobic hydration form a continuous fractal network of water molecules. Most likely, a fractal network of clathrates and clusters of structured water is formed around the source of hydrophobic hydration (sodium oleate molecules), the size of which will depend on the degree 
of hydrophobic hydration of the system. A sufficiently high concentration of molecules-centres of hydrophobic hydration is required to convert the entire volume of water into a fractal network, but this can be done to a certain extent, exceeding which will lead to their aggregation (in particular, the formation of sodium oleate micelles), which will limit the increase in fractal volume grids. To increase the size of the fractal grid, it is advisable to increase the degree of structuring of the water. According to the literature, alcohols regulate the water structure. That is, in the presence of alcohol, due to hydrophobic interactions, water is already partially structured. This is confirmed by the results of studies presented, which shows the feasibility of simultaneous use for structuring water of polyalcohols and colloidal hydrophobic surfactants.

In determining the effectiveness of the use of nanomodifiers to increase the strength of fine-grained concrete, as follows from the results (Fig. 1-7), the phenomenon of synergism is natural. This is obviously due to the dispersing effect of the applied nanomodifiers on the cement particles and the change in the conditions of interaction with the additive-modifier, which occurs in the middle of the MPAR micelle. In this case, adsorption layers are formed on the surface of clinker minerals, which, however, do not slow down the diffusion of hydroxide ions and the formation of crystal hydrates, but only translate this process deep into the micelles.

Obviously, such a mechanism of influence of MPAR micelles is a factor in regulating the formation of hydration products of clinker minerals, which leads to an increase in the rate of formation and the final strength of fine-grained concrete.

But, at the same time, this mechanism negatively affects the process of interaction of clinker minerals with microsilica (Fig. 3). This reduces the effect of introducing microsilica into the hardening cement system and cannot be recommended for use.

Comparison of the strength of fine-grained concrete containing various mineral additives-modifiers (Fig. 8) allows us to conclude that the most effective nanomodifier is the system "gypsum - MPAR".

As for the use of kaolin as a mineral additive-modifier, it should be noted that the experiments did not use metakaolin - a product of kaolin processing, but directly natural kaolin. In this case, the use of nanomodifier is a system of "kaolin - MPAR" leads to a slight (up to $25 \%$ ) increase in the strength of fine-grained concrete. Quite a significant increase in the strength of fine-grained concrete occurs when using a 
nanomodifier as a system "kaolin - a substance that gives an alkaline reaction - MPAR". In this case, the increase in the strength of finegrained concrete reaches $40 \%$.

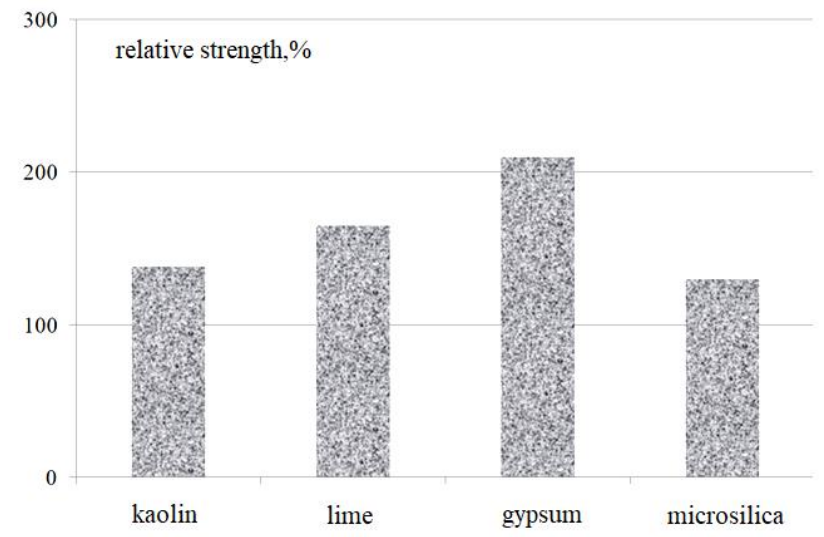

Fig. 8. The influence of the type of mineral additive-modifier on the strength of fine-grained concrete (MPAR content $-\mathbf{0 . 0 0 0 4 \%}$ )

This coincides with the results of studies ${ }^{12}$, where it was proved that for the activation of natural kaolin it is necessary to treat it with alkali metal compounds (in the conditions of the experiment - sodium carbonate, which is recommended ${ }^{13}$ ).

With regard to the use as a mineral additive-modifier of lime, it should be noted a fairly high efficiency (Fig. 5).

The optimal amount of lime, i.e. its amount, which provides maximum strength of concrete, is $1.3-1.4 \%$ by weight of cement.

As the results of experiments show (Fig. 5), when used as an additive-modifier of gypsum or lime, the processes of forming the strength of concrete in the initial period of its hardening (3 days) are accelerated. In the future, the rate of formation of the strength of

12 Дудина С.Н. Сорбция из растворов ионов $\mathrm{Fe}^{3+}$ и $\mathrm{Ni}^{2+}$ природными и активированными глинами. Научные ведомости. 2010. Вып. 9 (80). С. 131-136.

18. Шишкина А.А. Влияние мицеллообразующих ПАВ на свойства бетона. Вісник Одеської державної академї будівництва та архітектури. 2015. 60. C. 359-364.

13 Тевяшев, А.Д., Шитиков Е.С. О возможности управления свойствами цементобетонов с помощью нано-модификаторов. Восточно-Европейский журнал передовых технологий. 2009. № 4/7 (40). С. 35-40. 
concrete, which contains a nanomodifier using lime or gypsum, even more than the rate of formation of the strength of concrete, which contains only MPAR and concrete without additives. Based on the above, it can be concluded that lime and gypsum increase the efficiency of micellar catalysis of hydrosilicate synthesis in the process of hardening of cement paste. This does not differ from the data well known from the works.

Studies by many authors have proven the effectiveness of using a variety of substances whose particles have a size of less than $100 \mathrm{~nm}$, i.e. belong to the nanoparticles.

For all studies where nanoparticles were used, it is common to use surfactants (surfactants) based on the general laws of colloid chemistry to obtain stable suspensions of nanoadditives. This is described quite fully $\mathrm{in}^{14}$, where it is determined that the stability of the vast majority of technical aqueous dispersions of mineral nanoparticles is achieved due to the presence of emulsifiers - diphilic surfactants.

The limiting adsorption of surfactants at the interfacial boundary "nanoparticle - water" usually exceeds the critical concentration of micelle formation (CCM) of this surfactant in the aqueous medium. That is, in this case, artificially formed surfactant micelles are filled with solid particles that have nanoscale sizes (carbon nanotubes, microsilica, etc.). Thus, in the work on the study of the effect of nanoadditives on the strength of concrete, the particles of nanoadditives were coated with surfactant molecules, which came into contact with cement minerals and, as a consequence, led to the modification of concrete - increasing its strength.

Confirmation of this conclusion is the results of studies presented ${ }^{15}$, where it is shown that the use of only surfactants of a certain type as a modifying additive leads to an increase in concrete strength by $50-60 \%$, which is much higher than in the case of filled micelles. In these cases, the consumption of surfactants is much less than the CCM and, obviously, the physics of the processes that occur, can be described by

14 Шишкін О.О. Дослідження впливу сполук перехідних елементів на міцелярний каталіз формування міцності реакційного порошкового бетону. Восточно-Европейский журнал передовых технологий. 2016. Вып. 2/6 (80). С. $60-65$.

15 Дудина С.Н. Сорбция из растворов ионов $\mathrm{Fe}^{3+}$ и $\mathrm{Ni}^{2+}$ природными и активированными глинами. Научные ведомости. 2010. Вып. 9 (80). С. 131-136. 
the effect of ultra-low doses ${ }^{16}$. The article ${ }^{17}$ confirmed the conclusion of Academician P.O. Rebinder that hydrophilic surfactants used in small doses increase the strength of concrete.

However, it should be noted that the results of determining the strength of fine-grained concrete, which contains a nanomodifier in the form of a system of "microsilica - MPAR" (Fig. 4), indicate an ambiguous effect of MPAR on the change in mechanical strength. This is manifested, first of all, in the fact that the effectiveness of this nanomodifier is less than the effectiveness of microsilica without MPAR.

Such uncertainty imposes certain restrictions on the use of the obtained results regarding the choice of mineral additives-modifiers. This gives rise to a potentially interesting direction of further research, which, in particular, may be focused on identifying types of mineral additivesmodifiers as components of the nanomodifier, which lead to a decrease in its effectiveness.

\section{CONCLUSIONS}

1. The research established the peculiarities of the impact on compressive strength of fine-grained concrete nanomodifier, which is a dispersed system "additive-modifier - MPAR", depending on the type and amount of additive-modifier, as well as the amount of MPAR in concrete. Due to this, it can be argued that the dispersed system "additive-modifier - MPAR" significantly affects the formation of the structure of fine-grained concrete at all stages of its hardening. This is manifested in changes in the rate of formation and the amount of compressive strength of fine-grained concrete.

2. Each type of additive-modifier has its own features of forming the structure of fine-grained concrete, containing a dispersed system "additivemodifier - MPAR", which are the magnitude and rate of formation of compressive strength of fine-grained concrete. Thanks to the mechanism of micellar catalysis, the mechanical strength of concrete increases by $20 . .150 \%$ in comparison with concrete, which does not contain a dispersed system "mineral additive-modifier - MPAR".

${ }^{16}$ Шишкина А.А. Влияние мицеллообразующих ПАВ на свойства бетона. Вісник Одеської державної академії будівниџтва та архітектури. 2015. 60. C. 359-364.

17 Тевяшев А.Д., Шитиков Е.С. О возможности управления свойствами цементобетонов с помощью нано-модификаторов. Восточно-Европейский журнал передовых технологий. 2009. № 4/7 (40). С. 35-40. 
3. The conducted researches allow to assert about efficiency of use of the nanomodifier containing kaolin, lime, gypsum as additive modifier. The use of microsilica as a mineral additive-modifier requires additional research. The obtained results indicate the possibility of targeted regulation of the processes of forming a strong structure of fine-grained concrete by using a complex nanomodifier, which contains colloidal surfactants that are able to form micelles and additive-modifier.

4. The explanation of certain effects is possible on the basis of the mechanism of hydrophobic interactions in the system "water - hydrophobic surfactant". In general, water is a highly structured liquid with partial preservation of the tetrahedral ice-like openwork structure and the presence of unbound water molecules. The specific structure of water is the cause of hydrophobic interactions between non-polar molecules or radicals in an aqueous medium (solution). The term "hydrophobic interactions" was introduced by Kautsmann to describe the mutual attraction of nonpolar groups in the aquatic environment. According to O.Ya. Samoilov, hydrophobic hydration is to stabilize the structure of water by particles of solute. Thus, hydrophobic interactions occur only in aqueous solutions as a result of the interaction of polar water molecules with non-polar hydrophobic particles (hydrocarbons) or non-polar radicals of molecules, in particular, non-polar surfactant radicals. The main cause of hydrophobic interactions that lead to the formation of micellar surfactant solutions is associated with structural changes that occur in water when dissolving hydrocarbons in it. These structural changes in water cause low solubility of hydrocarbons in it, which is not associated with an increase in energy, but with a decrease in entropy during dissolution. Hydrophobic hydration is found in the case of complex organic ions and molecules of a number of non-electrolytes. It is due to the inhibitory effect of dissolved particles on the translational motion of water molecules in solution. In contrast to hydrophilic hydrophobic hydration is not the result of enhanced interaction of water molecules and solute, but rather occurs as a result of enhanced interaction between $\mathrm{H}_{2} \mathrm{O}$ molecules, thereby contributing to the structuring of free water. The collective motion of water molecules in a spatial grid seeks to preserve their tetrahedral coordination, which characterizes the ability of water molecules to form an infinite branched cluster. This preserves the structural inhomogeneity of the grid of hydrogen bonds, which is manifested in the uneven distribution in the space of molecules, the presence of "voids", which correspond in size to the water molecule. 
At this stage of development of concrete technology, the increase in its strength is carried out in two ways: either use high-activity cement, or reduce the water-cement ratio in concrete.

The first way has its limitations, namely the high cost of high-grade cement.

The second way - reducing the water content in concrete with a constant amount of cement is more rational and therefore usually accepted in modern technology. However, this solution has its drawbacks, namely the deterioration of the plasticity of the concrete mixture while reducing water consumption in concrete. Therefore, in this case increasing quality of concrete (its durability) lose technological properties of concrete mix. To preserve the plasticity of the concrete mixture, a solution was invented - to use surfactants as plasticizers. But now when the water content in concrete decreases, its strength increases, the use of surfactants is maintained and even improves the plasticity of the concrete mixture, but the time of its hardening increases, which complicates the process of manufacturing concrete structures. To accelerate the hardening of the concrete mixture, accelerators are added to its composition, which, in turn, contribute to the negative effects of concrete hardening, namely, or lead to the destruction of reinforcement, or contribute to the formation of hydration products of cement, which are not classic for this system, to its destruction. There is also the problem of compatibility of a certain cement with a certain surfactant, i.e. there are cases when the applied surfactant in a pair with one cement has positive effects, and in a pair with another cement does not show positive effects.

In addition, each binder has its own optimal water-binding ratio, which most effectively implements its cementing properties. Deviations from the optimal water-binding ratio in the direction of its increase or decrease lead to insufficient use of the potential of the material, and in the transition to systems with high concentrations - even to a violation of the structure. Portland cements in concretes, made even at high water-cement ratios $(0.45 \ldots 0.6)$, within $10 \ldots 15$ years reach the degree of hydration only in $70 \ldots 85 \%$. Given this circumstance, obviously, the dangerous threshold of concentration limits of these binders lies at lower water-cement ratios.

At long hardening of a cement stone with water-cement ratios of $0.05 \ldots 0.2$ (3...4 years and more) the phenomenon of relaxation of its internal stresses is observed. This is reflected in the volumetric expansion of cement stone, which, reaching a maximum of about 1 year, further decreases. Obviously, during a long stay of cement stone in a humid environment there is a recrystallization of hydrates, and first of all hydrate of calcium oxide, 
with their movement from tense sites of the hardened system in free cavities of structure with decrease in its porosity to values lower than earlier specified on $25 . . .28 \%$.

The results of research obtained in the work allow us to conclude that surfactants in concrete should not solve the problems for which they are currently used.

That is, the use of colloidal hydrophobic aliphatic surfactants, as well as most hydrophilic surfactants, in extremely low concentrations will provide a significant increase in physical and mechanical properties of concrete without significantly reducing the water content, or without reducing the water content. This technological solution will reduce the chemical load on the concrete, provide sufficient plasticity of the concrete mixture and hardening time, simplify and reduce the cost of technology for the manufacture of concrete and reinforced concrete products.

\section{SUMMARY}

The influence of nanomodifiers, which consist of a mixture of surfactant that forms micelles, and mineral additives-modifiers, has been studied. A feature of the research was the study of the simultaneous effect of surfactants that form micelles and mineral additives-modifiers on the change in the strength of fine-grained concrete. The most widely used modifier additives today are microsilica and metakaolin. However, they have certain disadvantages. The disadvantages of microsilica include the lack of stability of its properties, as it is a waste product. Metakaolin has a high cost due to the relatively high energy consumption for its production. Therefore, microsilica, lime, gypsum and natural kaolin were used as additives in the studies. In the course of research, it was established that the use of nanomodifiers, which consist of micellar solutions and mineral additives-modifiers, changes the rate of formation and the strength of fine-grained concrete. As shown by the results of experiments, when used as an additive-modifier of gypsum or lime, the processes of forming the strength of concrete in the initial period of its hardening ( 3 days) are accelerated by 1.5-2 times. In the future, the rate of formation of strength of concrete, which contains a nanomodifier using lime or gypsum, still continues to exceed the rate of formation of strength of concrete, which contains only MPAR and concrete without additives. At the age of 28 days, nanomodified concrete has a strength that is $70-110 \%$ higher than the strength of concrete without additives. 


\section{REFERENCES}

1. Murthy A.R.C., Palani G.S., Iyer N.R. Impact Analysis of Concrete Structural Components. Defense Science Journal. 2010. No. 60(3). Pp. 307-319.

2. Каприелов С.С., Шейнфельд А.В., Кардумян Г.С. Новые модифицированные бетоны : монографія. Москва : Парадиз, 2010. $258 \mathrm{c}$.

3. Haifeng L., Jianguo N. Mechanical behaviour of reinforced concrete subjected to impact loading. Mechanics of Materials. 2009. Issue 41(12). Pp. 1298-1308.

4. Iqbal M.A., Rajput A., Bhargava P. Plain and reinforced concrete targets subjected to projectile impact. Procedia Engineering. 2017. Issue 173. Pp. $138-144$.

5. Пономарев А.Н. Высококачественные бетоны. Анализ возможностей и практика использования методов нанотехнологии. Инженерно-строительный журнал. 2009. Вып 6. С. 25-33.

6. Толстой А.Д., Лесовик В.С., Загороднюк ЈІ.Х., Ковалева И.А. Порошковые бетоны с применением техногенного сырья. Вестник МГСУ. 2015. Вып. 11. С. 101-109.

7. Шишкіна О.О. Дослідження впливу нанокаталізу на формування міцності реакційного порошкового бетону. Восточно-Европейский журнал передовых технологий. 2016. Вып. 1/6 (79). С. 55-60.

8. Шишкіна О.О. Дослідження впливу поверхнево-активних речовин, що утворюють міцели, на міцність ніздрюватого реакційного порошкового бетону. Восточно-Европейский журнал передовых технологий. 2016. Вып. 2/6 (80). С. 66-70.

9. Shishkina A., Shishkin A., Vatin, N. Low-shrinkage alcohol cement concrete. Applied Mechanics and Materials. 2014. Vols. 633-634. Pp. 917-921.

10. Батраков, В.Г., Каприелов С.С., Иванов Ф.М., Шейнфельд А.В. Оценка ультрадисперсных отходов металлургических производств как добавок в бетон. Бетон и железобетон. 1990. Вып. 12. С. 15-17.

11. Баженов, Ю.М. Технология бетона. Москва : АВС, 2003. 500 с.

12. Рунова, Р.Ф., Руденко И.И., Троян В.В., Товстонис В.В., Щербина С.П., Пашина Л.Д. Формирование структуры высокопрочных бетонов. Будівельні матеріали, вироби та санітарна техніка. 2008. Вип. 29. С. 91-97. 
13.Барабаш И.В., Ксьоншкевич Л.М., Крантовська О.М. Високоміцні бетони на механоактивованому в'яжучому. Збірник наукових праць УкрДАЗТ. 2014. Вип. 149. С. 130-136.

14. Jo B.-W. Characteristics of cement mortar with nano- $\mathrm{SiO}_{2}$ particles. Construction and Building Materials. 2007. No. 21. Pp. 1351-1355.

15. Морозов Н.М., Боровских И.В. Влияние метакаолина на свойства цементных систем. Известия КГАСУ. 2015. Вып. 3(33). C. $127-132$.

16. Шишкін О.О. Дослідження впливу сполук перехідних елементів на міцелярний каталіз формування міцності реакційного порошкового бетону. Восточно-Европейский журнал передовых технологий. 2016. Вып. 2/6 (80). С. 60-65.

17. Дудина С.Н. Сорбция из растворов ионов $\mathrm{Fe}^{3+}$ и $\mathrm{Ni}^{2+}$ природными и активированными глинами. Научные ведомости. 2010. Вып. 9 (80). С. 131-136.

18. Шишкина А.А. Влияние мицеллообразующих ПАВ на свойства бетона. Вісник Одеської державної академії будівничтва та архітектури. 2015. № 60. С. 359-364.

19. Тевяшев, А.Д., Шитиков Е.С. О возможности управления свойствами цементобетонов с помощью нано-модификаторов. Восточно-Европейский журнал передовых технологий. 2009. № 4/7 (40). С. 35-40.

Information about authors: Shishkina A. A.,

Candidate of Technical Sciences, Associate Professor, Associate Professor at the Department of Technology of Building Products, Materials and Structures Kryvyi Rih National University 11, V. Matusevicha str., Kryvyi Rih, Dnipropetrovsk region, 50027, Ukraine

Shishkin A. A.,

Doctor of Technical Sciences, Professor, Head of the Department of Technology of Building Products, Materials and Structures

Kryvyi Rih National University 11, V. Matusevicha str., Kryvyi Rih, Dnipropetrovsk region, 50027, Ukraine 